\title{
ANALISIS MODAL PINJAMAN DAN RENTABILITAS EKONOMI PADA KOPERASI PEGAWAI REPUBLIK INDONESIA (KPRI) KARYA BHAKTI DINAS KOPERASI UMKM PERINDUSTRIAN DAN PERDAGANGAN PROVINSI SULAWESI TENGAH
}

\author{
KHARISMAN HASLAN \\ MUSLIMIN \\ MUHAMMAD FAISAL \\ Prodi Manajemen, Fakultas Ekonomi, Universitas Tadulako \\ Email: kharismanHaslan@yahoo.com
}

\begin{abstract}
This research aims to determine, understand, and analyze the influence of capital lending and economic profitability on the cooperative for The Indonesian Republic officials 'Karya Bhakti' of The Departement of Industry Cooperation and Trading at Central Sulawesi Province. It is a descriptive research using quantitative and qualitative approach that consists of primary data and secondary data. Data collection method to obtain the primary data is observation on Karya Bhakti Employee Cooperative as the subject of research and secondary data obtained from the financial annual report Karya Bhakti Cooperative. The analysis of loan capital and economic profitability of Karya Bhakti Cooperative is measured by using trend analysis. Based on the data analysis from 2008 to 2013, it indicates that the development of Loan capital has increased every year. This is due to the development of the business managed by the cooperatives operations, while the development of the economic profitability has been fluctuated, as well as the result of trend analysis of capital lending and economic profitability showed an increase every year.
\end{abstract}

Keywords: capital lending, profitabilityeconomic and trend analysis

\begin{abstract}
Abstrak
Penelitian ini bertujuan untuk mengetahui, memahami dan menganalisa modal pinjaman dan rentabilitas ekonomi pada KPRI Karya Bhakti Provinsi Sulawesi Tengah. Penelitian ini merupakan penelitian deskriptif, dengan menggunakan pendekatan kuantitafif dan kualitatif yang terdiri dari data primer dan data sekunder. Dimana peneliti mendeskripsikan hasil penelitian dengan menggunakan angka. Proses pengumpulan data penelitian ini menggunakan metode observasi yaitu pengumpulan data primer pada KPRI Karya Bhakti yang menjadi objek penelitiandan data sekunder berupa laporan keuangan yang diperoleh dari laporan tahunan KPRI Karya Bhakti. Untuk mengukur Analisis modal pinjaman dan Rentabilitas Ekonomi KPRI Karya Bhakti menggunakan Analisis Trend.

Berdasarkan hasil analisis data pada tahun 2008 - 2013 menunjukan bahwa perkembangan modal pinjaman mengalami kenaikan ditiap tahunnya hal ini disebabkan karna adanya perkembangan usaha yang dikelola koperasi dimana modal pinjaman dibutuhkan untuk mendukung atau membiayayi kegiatan oprasional usaha koperasi. sedangkan perkembangan rentabilitas ekonomi mengalami kenaikan dan penurunan. Serta hasil analisis trend modal pinjaman dan rentabilitas ekonomi menunjukan adanya peningkatan ditiap tahunnya.
\end{abstract}

Kata Kunci: Modal pinjaman, Rentabilitas Ekonomi, dan Analisis Trend

\section{PENDAHULUAN}

Laju pertumbuhan perekonomian Indonesia saat ini dikenal ada tiga pelaku ekonomi yaitu; Perusahaan Swasta, Badan Usaha Milik Negara (BUMN) dan Koperasi yang telah memberikan kontribusi terhadap perkembangan ekonomi dan proses pembangunan di Indonesia. Koperasi dalam melaksanakan kegiatan usaha koperasi harus didukung oleh faktor-faktor produksi, salah satunya adalah modal. Modal dalam koperasi diperoleh dari simpanan anggota dan sumber permodalan lainnya. Melalui modal inilah koperasi akan melakukan usahanya sesuai dengan jenis koperasi. Modal 
Haslan, K.

yang ada akan dikelola oleh pengurus sesuai dengan kesepakatan bersama antara pengurus dan anggota.

Secara umum sumber modal dapat digolongkan dalam dua golongan yakni dari dalam (intrenal) dan dari luar (eksternal). Sumber modal dari dalam, bersumber dari setoran pemilik, sedangkan dari luar dapat berupa pinjaman dari bank dan lembaga keuangan non bank.Pemanfaatan modal sendiri dan modal pinjaman salah satunya yaitu pembiayaan operasional usaha untuk memperoleh profit (keuntungan). Hal ini dapat dilihat secara langsung dalam laporan keuangan koperasi. Laporan keuangan memberikan gambaran mengenai kondisi keuangan pada saat tertentu, prestasi operasi dalam suatu rentang waktu, serta informasi-informasi lainnya. Ditinjau dari sudut pandang manajemen, laporan keuangan merupakan media untuk mengkomunikasikan performance keuangan kepada pihak-pihak yang berkepentingan. Sedangkan ditinjau dari sudut pandang pemakai laporan keuangan diharapkan dapat digunakan untuk mengambil keputusan yang rasional dalam praktek bisnis yang sehat. Untuk menilai kondisi keuangan dan prestasi koperasi diperlukan beberapa tolok ukur, salah satunya yaitu analisis rasio keuangan yang menghubungkan data-data keuangan yang satu dengan lainnya (Andriani:2009).

Salah satu jenis koperasi yang tumbuh dan berkembang di kota Palu adalah Koperasi Pegawai Republik Indonesia (KPRI). Keberadaan KPRI sangat membantu dalam menyediakan sarana dan prasarana bagi Pegawai pada khususnya dan masyarakat pada umumnya. Wujud dari usaha KPRI tersebut diantaranya adalah penyediaan sarana simpan pinjam, penyediaan alat-alat tulis, kebutuhan rumah tangga, alat telekomunikasi, dan sebagainya.

Berdasarkan laporan keuangan dapat diketahui aktivitas manajemen, yang meliputi pembelanjaan dan investasi didalam KPRI Karya Bhakti provinsi Sulawesi Tengah termasuk berapa besar jumlah dana yang tersedia dan kemampuan koperasi dalam menghasilkan laba operasi selama periode tertentu, dan sebagai bahan dalam mengungkapkan berbagai pengaruh mengenai pencapaian dan keberhasilan suatu koperasi pada periode tertentu.

Simpanan anggota (simpanan pokok, simpanan wajib dan simpanan sukarela), merupakan sumber dana yang ada di koperasi, sehingga besar kecilnya simpanan anggota berpengaruh pada operasional usaha yang akhirnya dapat berdampak pada pencapaian keuntungan/laba operasi dalam koperasi tersebut. Simpana sukarela bisa dipergunakan oleh pihak koperasi sebagai modal usaha sehingga anggota sebagai pihak penyimpan atau anggota yang melakukan simpanan sukarela nantinya akan mendapatkan bagian dari hasil usaha yang dikembangkan oleh koperasi tersebut melalui simpanan yang dia berikan.

Modal pinjaman merupakan salah satu pendukung dari modal tersebut. Penggunaan modal pinjaman inilah menjadi sebuah polemik, ketika koperasi sangat bergantung kepada sumber dana dari luar maka di satu sisi harus ada jaminan bahwa koperasi mampu menambah pendapatannya melalui modal pinjaman ini. Penggunaan modal pinjaman ini secara tidak langsung akan berpengaruh juga terhadap laba, apakah terjadi peningkatan laba atau sebaliknya.

Adanya modal pinjaman juga akan memberi dampak tersendiri yaitu beban finansial jika itu berasal dari bank atau lembaga keuangan lainnya yang menerapkan bunga pinjaman, sehingga dibutuhkan kecermatan dalam pencarian dan pemanfataan modal pinjaman. Besar kecilnya rentabilitas ini tergantung dari besarnya keuntungan yang diperoleh dan modal yang dimiliki dalam menjalankan usaha koperasi. Selain ditunjang oleh pemenuhan modal yang tepat agar koperasi dapat berkembang dengan baik,pengeloloaan yang efektif dan efisien serta produktif pun akan sangat berpengaruh terhadap kinerja koperasi. Modal haruslah menjadi jumlahnya,tetapi harus dijaga agar modal kerja tidak sampai berlebihan.

Diharapkan dengan adanya modal yang tinggi pencapaian laba (profit) tinggi serta dicapainya tingkat rentabilitas yang efisien.Dimana modal asing sifatnya sementara (wajib dikembalikan) dan bunganya harus dibayar, jadi perusahaan mempunyai beban biaya tetap. (Hasibuan, 2011:65) 
Tabel 1 Laporan Neraca KPRI Karya Bhakti Periode 2008-2013

\begin{tabular}{|c|c|c|c|c|c|c|c|}
\hline \multirow{3}{*}{ No } & \multirow{3}{*}{ Uraian } & \multicolumn{6}{|c|}{ Tahun } \\
\hline & & 2008 & 2009 & 2010 & 2011 & 2012 & 2013 \\
\hline & & \multicolumn{6}{|c|}{ (dalam $\mathrm{Rp}$ ribuan) } \\
\hline $\mathrm{I}$ & Aktiva Lancar & 595.777 & 676.237 & 953.912 & 1.293 .388 & 1.506 .348 & 2.208 .970 \\
\hline II & Investasi Jk. Panjang & 15.783 & 15.783 & 27.583 & 56.043 & 67.728 & 94.475 \\
\hline III & Aktiva Tetap & 22.403 & 63.368 & 94.953 & 145.767 & 140.574 & 169.800 \\
\hline \multirow[t]{2}{*}{ IV } & Aktiva Lain-lain & 15.049 & 14.051 & 13.053 & 12.054 & 10.535 & 9.625 \\
\hline & Jumlah Aktiva & 49.014 & 769.440 & 1.089 .502 & 1.507 .253 & 1.725 .186 & 2.482 .871 \\
\hline $\mathrm{V}$ & Kewajiban Lancar & 118.202 & 168.182 & 183.254 & 228.501 & 244.213 & 302.109 \\
\hline \multirow[t]{2}{*}{ VI } & $\begin{array}{l}\text { Kewajiban Jk. } \\
\text { Panjang }\end{array}$ & 257.701 & 234.653 & 483.287 & 739.897 & 813.711 & 1.414 .117 \\
\hline & Jumlah Kewajiban & 03 & 402.835 & 666.541 & 968.398 & 1.057.924 & 1.716.226 \\
\hline
\end{tabular}

Sumber : Laporan Neraca KPRI Karya Bhakti, data diolah

Pada Tabel 1 memperlihatkan setiap tahunnya perkembangan Neraca KPRI Karya Bhakti Provinsi Sulawesi Tengah terus mengalami peningkatan dari periode 2008-2013. Ini dapat dilihat pada uraian jumlah aktiva dan jumlah kewajiban yang meningkat, Dimana pada tahun 2008 jumlah aktiva sebesar Rp.649.014.000 menjadi Rp.769.440.000 atau meningkat 18,58\% pada tahun 2009, hal ini disebabkan karna meningkatnya jumlah simpanan pokok, simpanan wajib, cadangan koperasi dan juga piutang, persediaan barang Waserda, persediaan barang ATKsertaterjadi penambahan modal pinjaman dari simpanan sukarela pada KPRI Karya Bhakti yang berasal dari pembagian SHU tiap anggota yang secara otomatis anggota tanamkan sebagai simpanan sukarela, hal ini menunjukan adanya kesadaran anggota akan kebutuhan modal pada KPRI Karya Bhakti sehingga modal pada koperasi pun bertambah dan juga koperasi membayar kewajiban jangka panjang dana kesejahteraan anggota.

Pada tahun 2010 sebesar Rp.1.089.502.000 atau meningkat 41,60\%, hal ini disebabkan meningkatnya jumlah piutang, persediaan barang,peralatan usaha dibanding dengan tahun 2009 di samping itu juga terjadi pembayaran pinjaman dan bunga pinjaman hutang dagang, dan hutang bank yang dapat mengurangi modal akan tetapi juga terjadi penambahan modal pinjaman dari simpanan sukarela dan sumber lain sehingga dapat menambah jumlah modal. Dan pada tahun 2011 meningkat sebesar Rp.1.507.253.000 atau 38,34\% dari tahun sebelumnya di karnakan tejadi peminjaman pada bank yang mengakibatkan modal bertambah dan terjadinya pembagian SHU kepada anggota koperasi

Serta pada tahun 2012 sebesar Rp.1.725.186.000 atau meningkat 14,46\% dikarnakan meningkatnya jumlah simpanan pokok, simpanan wajib, donasi, cadangan Koperasi dan SHU tahun berjalan dimana modal pada koperasi juga bertambah sehingga koperasi dapat mendanai seluruh kewajiban jangka pendek yang akan jatuh tempo.

Pada tahun 2013 sebesar Rp.2.482.871.000 atau meningkat 43,92\% hal ini dikarnakan terjadi peningkatan pada simpana pokok, simpanan wajib, cadangan koperasi, piutang dagang, piutang pinjaman anggotadan persediaan. Besarnya total modal ini dapat menjadi keuntungan bagi koperasi tersebut, karena dari jumlah modal yang besar dapat digunakan untuk meningkatkan skala usaha yang lebih besar untuk menghasilkan laba yang besar pula.

Tabel 2 Laporan Modal Pinjaman KPRI Karya Bhakti Periode 2008-2013

\begin{tabular}{|c|c|}
\hline Tahun & Modal Pinjaman (dalam Rp ribuan) \\
\hline 2008 & 375.903 \\
\hline 2009 & 400.305 \\
\hline 2010 & 666.541 \\
\hline 2011 & 968.398 \\
\hline 2012 & 1.057 .924 \\
\hline 2013 & 1.716 .226 \\
\hline
\end{tabular}

Sumber: Laporan Neraca KPRI Karya Bhakti, data diolah 
Berdasarkan tabel 2 dapat dilihat modal pinjaman KPRI Karya Bhakti Periode 2008-2013 mengalami peningkatan tiap tahunnya, dimana pinjaman padan tahun 2008 sebesar Rp.375.903.000 dikarnakan KPRI Karya Bhakti melakukan pinjaman pada Bank dan Lembaga Keuangan Lainnya sebesar Rp.188.705.000 dan sumber lain yang sah Rp.157.701.000 dan simpanan sukarela yang berasal dari anggota kopersai sebesar Rp.40.943.000

Pada tahun 2009 pinjaman koperasi sebesar Rp.400.305.000 atau meningkat 7,16\% dari tahun sebelumnya hal ini disebabkan kerena meningkatnya simpanan sukarela menjadi Rp.68.933.000 pinjaman pada bank dan lembaga keuangan lainnya tetap sebesar Rp.192.378.000 artinya KPRI Karya Bhakti belum melakukan pembayaran, sedangkan pada sumber lain yang sah terjadi pengurangan Rp.154.113.000 dikarenakan pembayaran pada dana kesejahteraan anggota. Pada tahun 2010 pinjaman koperasi sebesar Rp.666.541.000 atau meningkat 65,46\% dari tahun 2009 hal ini dikarenakan mengkatnya simpanan sukarela menjadi Rp.93.970.000 dan terjadi peningkatan pada hutang bank dan lembaga keuangan lainnya menjadi sebesar Rp.426.245.000 dikarenakan KPRI Karya Bhakti melakukan pinjaman pada Bank Kesejahtraan Ekonomi (BKE)walaupun telah melunasi hutang lancar yaitu hutang bank sebesar Rp.12.226.000 tapi tidak sebanding dengan pinjaman pada bank Bank Kesejahtraan Ekonomi sebesar Rp. 252.574.000 dan pinjaman pada sumber lain yang sah meningkat menjadi Rp.184.964.000

Pada tahun 2011 pinjaman koperasi sebesar Rp.968.398.000 atau meningkat 45,29\% dari tahun sebelumnya disebabkan karena meningkatnya simpanan sukarela sebesar Rp.94.574.000 dan terjadi peningkatan pada hutang bank dan lembaga keuangan lainnya menjadi sebesar Rp.684.726.000 dikarenakan KPRI Karya Bhakti kembali melakukan pinjaman pada Bank Kesejahtraan Ekonomi akumulasi dari tahun 2010-2011 sebesar Rp.519.693.000 sedangkan dari sumber lain juga terjadi peningkatan sebesar Rp.189.098.000 karena terjadi peningkatan pada hutang dagang.

Pada tahun 2012 pinjaman koperasi sebesar Rp.1.057.924.000 atau meningkat 9,24\% dari tahun 2011 hal ini dikarenakan meningkatnya simpanan sukarela pada KPRI Karya Bhakti sebesar Rp.110.927.000 dan terjadi peningkatan pada hutang bank dan lembaga keuangan lainnya menjadi sebesar Rp.763.794 dikarenakan KPRI Karya Bhakti kembali melakukan pinjaman pada Bank Kesejahtraan Ekonomi sebesar Rp.79.068.000 pada tahun 2012 sedangkandari sumber lain yang sah sebesar Rp.183.203.000 dikarnakan terjadi pembayaran pada hutang dagang.

Pada tahun 2013 pinjaman koperasi sebesar Rp.1.716.226.000 atau meningkat 62,23\% dari tahun 2012 hal tersebut dikarenakan bertambahnya kewajiban hutang pada Bank Kesejahtraan Ekonomi dan juga bertambahnya simpanan sukarela.

Tabel 3 Laporan Sisa Hasil Usaha (SHU) KPRI Karya Bhakti Periode 2008-2013

\begin{tabular}{|c|c|}
\hline Tahun & Sisa Hasil Usaha (dalam Rp ribuan) \\
\hline 2008 & 123.586 \\
\hline 2009 & 203.306 \\
\hline 2010 & 222.535 \\
\hline 2011 & 365.933 \\
\hline 2012 & 556.210 \\
\hline 2013 & 759.592 \\
\hline
\end{tabular}

Sumber: Laporan SHU KPRI Karya Bhakti, data diolah

Berdasarkan tabel 3 dapat dilihat dari data di atas Sisa Hasil Usaha (SHU) KPRI Karya Bhakti Periode 2008-2013 mengalami kenaikan tiap tahunnya. Tahun 2008 SHU Rp. 123.586.000, tahun 2009 SHU KPRI Karya Bhakti meningkat menjadi Rp. 203.306.000, SHU mengalami kenaikan dengan selisih sebesar Rp.79.702.000 dan perkembangan persentase sebesar 39,21\%, tahun berikutnya yaitu tahun 2009 ke tahun 2010 juga mengalami peningkatan sebesar Rp.19.229.000 dengan nilai persentase sebesar 8,64\%. Pada tahun 2011 mengalami kenaikan sebesar Rp.143.398.000 dengan nilai persentase sebesar 39,19\% dibanding tahun 2010. Pada tahun berikutnya yaitu tahun 2012 juga mengalami kenaikan sebesar Rp.190.227.000 dengan nilai persentase sebesar 34,21\%, dan pada tahun berikutnya yaitu tahun 2013 mengalami kenaikan sebesar Rp. 203.382 .000 dengan nilai persentasi sebesar 26,78\% dibanding tahun 2012.Kenaikan SHU KPRI Karya Bhakti yang paling tinggi terjadi 
pada tahun 2009 yaitu sebesar 39,21\% . Sedangkan Sisa Hasil Usaha (SHU) pada tahun 2010 mengalami peningkatan terendah sebesar $8,64 \%$ disebabkan terjadinya peningkatan beban usaha dan bunga bank dari tahun sebelumnya. Pada tahun berikutnya yaitu tahun 2011-2013 Sisa Hasil Usaha KPRI Karya Bhakti kembali mengalami kenaikan ini disebabkan pihak koperasi meminimalisir jumlah beban yang dikeluarkan.

\section{KAJIAN LITERATUR DAN PENGEMBANGAN HIPOTESIS}

Penelitian yang dilakukan Diah Miranty (2013) membahas mengenai Pengaruh Perputaran Piutang Dan Efisiensi Modal Kerja Terhadap Rentabilitas Ekonomi Pada KPRI Gotong Royong Kedungpring Lamongan. Variabel yang digunakan adalah variabel terikat/ variabel dependen (Y) Rentabilitas ekonomi dan variabel independen/ variabel bebas $(\mathrm{X}) \mathrm{X} 1=$ perputaran piutangX2 = Efisiensi modal kerja. Dan hasil penelitian diketahui uji $\mathrm{f}$ bahwa perputaran piutang dan efisiensi modal kerja secara bersama-sama berpengaruh signifikan terhadap rentabilitas ekonomis. Hasil dari koefisien determinasi penelitian ini sebesar $68,2 \%$ rentabilitas dipengaruhi oleh perputaran piutang, dan efisiensi modal kerja, dan 31,8\% dipengaruhi oleh variabel lain yang tidak diteliti dalam penelitian ini.

Penelitian Eka Novi Andriani. S (2009) dengan penelitiannya yang berjudul Pengaruh Modal Sendiri dan Modal Pinjaman terhadap tingkat Rentabilitas pada Koperasi Serba Usaha (KSU) di Kabupaten Blora. Penelitian ini menggunakan 1 (satu) variabel terkait yaitu rentabilitas (Y), dan 2 (dua) variabel bebas yaitu modal sendiri $\left(\mathrm{X}_{1}\right)$ dan modal pinjaman $\left(\mathrm{X}_{2}\right)$. Hasilpenelitian ini menunjukan bahwa modal sendiri dan modal pinjaman secara bersama-sama memberikan pengaruh terhadap rentabilitas modal sendiri pada Koperasi Serba Usaha (KSU) di Kabupaten Blora pada tahun 20042006. Hal ini ditunjukan pada uji simultan dengan tingkat signifikan 0,000 berarti $\mathrm{H}_{0}$ ditolak, dengan kata lain secara simultan atau bersama-sama modal sendiri dan modal pinjaman berpengaruh terhadap rentabilitas.

Penelitian yang dilakukan Made Ita Widiantari, I Ketut Suwarna, I Wayan Suwendra(2014) dengan judul Pengaruh Tingkat Suku Bunga Dan Perputaran Piutang Terhadap Rentabilitas Ekonomi Pada Koperasi. Dalam penelitian ini terdapat 1 variabel dependen (Y) Rentabilitas dan 2 variabel independen $(\mathrm{X}) \mathrm{X}_{1}$ : Tingkat Suku Bunga, $\mathrm{X}_{2}$ : Perputaran Piutang dengan hasil penelitian menunjukkan (1) ada pengaruh positif dan signifikan tingkat suku bunga dan perputaran piutang terhadap rentabilitas ekonomis, (2) ada pengaruh positif dan signifikan tingkat suku bunga terhadap perputaran piutang, (3) ada pengaruh positif tingkat suku bunga terhadap rentabilitas ekonomis, dan (4) ada pengaruh negatif dan signifikan perputaran piutang terhadap rentabilitas ekonomis.

Pada penelitian yang dilakukan oleh Mukhlis (2006) membahas tentang Pengaruh Modal Pinjaman Terhadap Rentabilitas Ekonomi pada Koperasi Pegawai Negeri (KPN) di Kota Palu. Variabel yang digunakan dalam penelitian ini terdiri atas 2 (dua) variabel utama, yaitu: Variabel independen $(\mathrm{X})$ modal pinjaman dan variabel dependen $(\mathrm{Y})$ dalam penelitian ini adalah rentabilitas ekonomi. Hasil penelitian ini menunjukan bahwa modal pinjaman (variabel X) mempunyai tingkat keeratan hubungan terhadap rentabilitas ekonomi KPN di Kota Palu dengan ketentuan bahwa $r>0$ artinya hubungan linier positif, yaitu makin besar nilai variabel $\mathrm{X}$ makin besar pula nilai variabel $\mathrm{Y}$, atau makin kecil variabel $\mathrm{X}$ makin kecil pula variabel $\mathrm{Y}$.

Penelitian yang dilakukan Sukardi Ikhsan (2011) dengan judul Analisis Rentabilitas Pada Koperasi Pegawai Republik Indonesia (KPRI) Di Jawa Tengah. Pada penelitian ini menggunakan 4 (empat) variabel Independen (Bebas) $\mathrm{X}_{1}$ : Likuiditas, $\mathrm{X}_{2}$ : Solvabilitas, $\mathrm{X}_{3}$ : Efisiensi pengendalian biaya, $\mathrm{X}_{4}$ : Size dan variabel dependen (Terkait) Rentabilitas Ekonomi dengan simbol Y. serta Hasilnya memperlihatkanbahwa solvabilitas, pengendalian biaya dan ukuran mempengaruhi rentabilitas ekonomi; Likuiditas tidak mempengaruhi rentabilitas ekonomi; dan likuiditas yang simultan , solvabilitas, pengendalian biaya dan size mempengaruhi rentabilitas ekonomi.

\section{METODE PENELITIAN Jenis Penelitian}

Metode penelitian yang digunakan dalam penelitian ini adalah metode analisis deskriptif metode ini bertujuan untuk menggambarkan sifat sesuatu yang tengah berlagsung pada saat riset 
Haslan, K.

dilakukan dan memeriksa sebab-sebab dari suatu gejala tertentu. Menurut Umar (2013:22). Dan menurut Sugiyono (2013:206) yaitu menganalisa data denagn cara mendeskripsikan atau menggambarkan data yang telah terkumpul sebagaimana adanya tanpa bermaksud membuat kesimpulan yang berlaku untuk umum atau generalisasi. Dimana teknik analisis deskriptif adalah teknik yang digunakan untuk menjelaskan variabel dalam penelitian ini dilakukan pengujian hipotesis hubungan antara kedua variable yaitu variable Modal Pinjaman dan variable Tingkat Rentabilitas.

\section{Objek Penelitian}

Berdasarkan judul di atas, yang menjadi objek dalam penelitian ini adalah Koperasi Pegawai Republik Indonesia ( KPRI ) Karya Bhakti Provinsi Sulawesi Tengah yang dinyatakan masih aktif oleh Dinas perindustrian, Perdagangan, Koperasi dan Penanaman Modal Kota Palu. Adapun objek penelitian ini adalah Modal pinjaman dan Rentabilitas Ekonomi

\section{Metode Analisis}

Analisis data diartikan sebagai upaya mengolah data menjadi informasi, sehingga karakteristik atau sifat-sifat data tersebut dapat dengan mudah dipahami dan bermanfaat untuk menjawab masalahmasalah yang berkaitan dengan kegiatan penelitian baik berkaitan dengan deskripsi data atau menarik kesimpulan tentang karakteristik populasi (parameter) berdasarkan data yang diperoleh dari sampel

(statistik).

Dalam penelitian ini, digunakan 2 (dua) metode analisis, yaitu:

1. Metode Kualitatif, yaitu metode penganalisaan data hasil temuan dengan menitikberatkan pada penginterprestasian sejumlah data temuan di lapangan maupun data perhitungan alat analisis.

2. Metode Kuantitatif, yaitu metode penganalisaan terhadap data primer, dengan menggunakan alat analisis. Dimana tujuan penelitian ini adalah untuk menganalisis modal pinjaman dan rentabilitas ekonomi pada KPRI Karya Bhakti

\section{Analisis Deskriptif}

Analisis deskriptif dimaksudkan untuk memberikan gambaran secara umum terhadap objek yang diteliti melalui data sampel atau populasi sebagaimana adanya, tanpa melakukan analisis dan bembuat kesimpulan yang berlaku secara umum. Adapun data yan diperoleh melalui hasil analisis deskriptif dilakukan dengan menyajikan dalam bentuk Tabel.

\section{Analisis Trend}

Menurut Kasmir (2014 : 82-83) Analisis Trend atau trendensi merupakan analisis laporan keuangan yang biasanya dinyatakan dalam presentase tertentu. Dalam analisis trend perbandingan analisis dapat dilakukan dengan menggunakan analisis horisontal atau dinamis. Data yang digunakan adalah data tahunan atau periode yang digunakan biasanya hanya dua atau tiga periode saja. Hal ini disebabkan jika lebih dari tiga periode, akan mengalami kesulitan untuk menganalisanya lebih cepat.

Dalam laporan keuangan perbandingan merupakan langkah yang teramat penting dalam proses analisa, hal ini dapat dipahami dari kenyataan bahwa saldo suatu akun di dalam laporan keuangan itu secara individual tidak memberikan informasi yang berarti, kecuali apabila diperbandingkan dengan data lain yang terdapat dalam laporan keuangan yang sama atau data sejenis dalam laporan keuangan yang berbeda.

Analisis laporan keuangan tidak lain merupakan suatu studi terhadap hubungan dari akun didalam laporan keuangan tersebut baik hubungan strukturan maupun hubungan trennya. Oleh karna itu di dalam analisis laporan keuangan pada garis besarnya, dapat digunakan teknik dan alat-alat analisis sebagai berikut;

1. Cross-Sectional Techniques, yang di dalam prakteknya dapat dilaksanakan melalui atau dalam bentuk:

(1) Analisis dalam Persentase perkomponen (Common Size Statement)

(2) Analisis Rasio (Rasio Analysis)

2. Time-Series Techniques, yang dilakukan dalam bentuk:

(1) Analisis Hubungan Tren (Trend Statement) 
(2) Analisis dalam Persentase perkomponen (Common Size Statement) (3) Analisis Rasio (Rasio Analysis)

Dari teknik dan alat analisis tersebut dapat diketahui bahwa analisis trend menggunakan TimeSeries Technique.

\section{HASIL DAN PEMBAHASAN \\ Hasil}

Tabel 4 Rentabilitas Ekonomi KPRI Karya Bhakti

Provinsi Sulawesi Tengah periode 2008-2013

\begin{tabular}{|c|c|c|c|}
\hline Tahun & $\begin{array}{c}\text { Sisa Hasil Usaha Sebelum } \\
\text { bunga dan pajak } \\
\text { (dalam Rp. Ribuan) }\end{array}$ & $\begin{array}{c}\text { Total Aktiva (dalam } \\
\text { Rp. Ribuan) }\end{array}$ & $\begin{array}{c}\text { Rentabilitas } \\
\text { Ekonomi }\end{array}$ \\
\hline 2008 & 123.586 & 649.014 & $19,04 \%$ \\
\hline 2009 & 203.306 & 769.440 & $26,42 \%$ \\
\hline 2010 & 222.535 & 1.089 .502 & $20,42 \%$ \\
\hline 2011 & 365.933 & 1.507 .253 & $24,27 \%$ \\
\hline 2012 & 556.210 & 1.725 .186 & $32,24 \%$ \\
\hline 2013 & 759.592 & 2.482 .871 & $30,59 \%$ \\
\hline
\end{tabular}

Sumber: Laporan SHU dan Neraca KPRI Karya Bhakti, data diolah

Berdasarkan tabel di atas, dapat diketahui bahwa SHU KPRI Karya Bhakti selalu mengalami kenaikan setiap tahun, yang menyebabkan peningkatan sisa hasil usaha KPRI Karya Bhakti adalah modal dan pendapatan usaha yang juga mengalami peningkatan. Serta pada pos rentabilitas ekonomi mengalami kenaikan dan penurunan. Dapat juga dilihat pada grafik berikut;

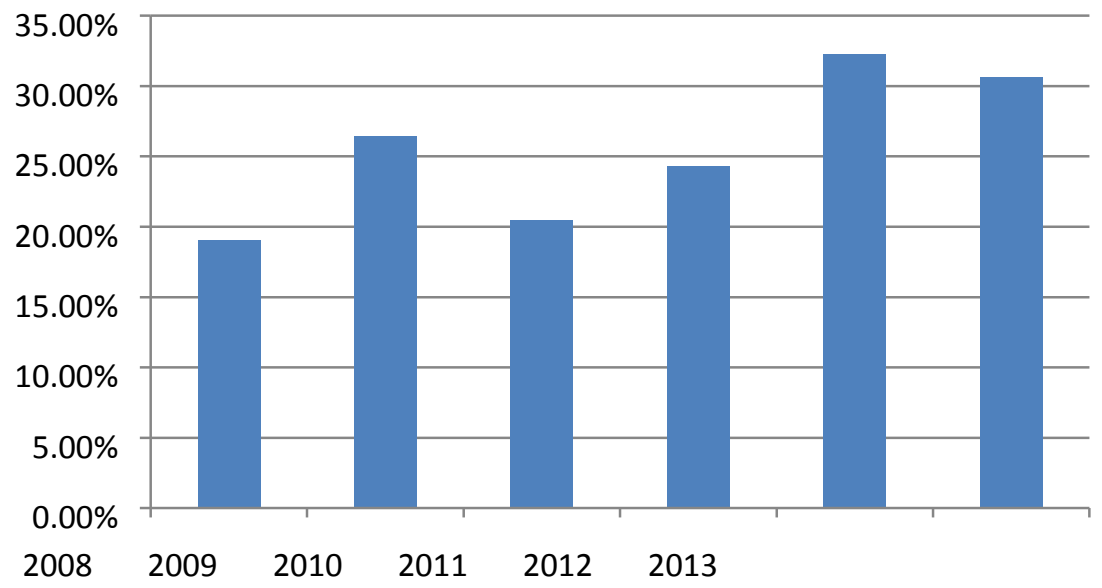

Gambar 1

Gramfik Rentabilitas Ekonomi KPRI Bhakti

Berdasarkan data diatas diketahui bahwa rentabilitas ekonomi pada Koperasi Pegawai Republik Indonesia (KPRI) Karya Bhakti periode 2008 - 2013 berfluktuatif atau naik turun, pada tahun 2012 Koperasi Pegawai Republik Indonesia (KPRI) Karya Bhakti yang memiliki nilai rasio rentabilitas ekonomi tertinggi dengan nilai sebesar 32,24\%, Hal ini memberikan arti bahwa setiap penambahan modal sebesar Rp. 1 maka KPRI Karya Bhakti mampu mendapatkan keuntungan sebesar Rp. 0,3224. Hal ini menunjukan KPRI Karya Bhakti pada tahun 2012 efektif dan efisien menggunakan modalnya, dalam arti manajemen koperasi mampu memanfaatkan modal yang dimiliki untuk oprasional jenis-jenis usaha yang dibutuhkan oleh koperasi sehingga perputaran modal berjalan dengan lancar dan dapt memberikan keuntungan pada koperasi, Adapan jenis-jenis usaha yang didanai oleh KPRI Karya Bhakti yaitu waserda/fotocopy, voucer pulsa, pospay, dan unit simpan pinjam yang 
memberikan fasilitas kredit untuk para anggota koperasi yang membutuhkan dan memberikan keuntungan pada koperasi.

KPRI Karya Bhakti pada tahun 2008 memiliki nilai rasio rentabilitas ekonomi terendah yaitu sebesar $19,04 \%$, hai ini menunjukan bahwa tingkat efisiensi dan efektifitas penggunaan modal yang rendah, dimana modal sebesar Rp. 1 hanya dapat menghasilkan Rp. 0,1904.Berarti bahwa manajemn koperasi kurang mampu memanfaatkan modal kerjanya dibanding dengan tahun-tahun berikutnya yang mana untuk membiayai atau membelanjai kegiatan operasionalisasi dari jenis-jenis usaha pada koperasi sehingga perputaran modal tidak terlalu menguntungkan untuk koperasi. Dapat dilihat laba yang dihasilkan pada tahun 2013 yaitu sebesar Rp. 759.592.000 lebih besar dibanding tahun 2012 sebesar Rp. 556.210.000, hal ini mengartikan bahwa besarnya laba belum dapat menentukan besarnya rasio rentabilitas ekonomi yang tinggi dikarnakan harus membandingkan dengan Total Aktiva yang dimiliki oleh KPRI Karya Bhakti tersebut.

Tabel 5 Data Modal Pinjaman KPRI Karya Bhakti

Provinsi Sulawesi Tengah periode 2008-2013

\begin{tabular}{|c|c|c|}
\hline Tahun & $\begin{array}{c}\text { Modal pinjaman (dalam } \\
\text { Rp. Ribuan) }\end{array}$ & $\begin{array}{c}\text { Selisih } \\
\text { (dalam Rp. Ribuan) }\end{array}$ \\
\hline 2008 & 375.903 & 24.402 \\
\hline 2009 & 400.305 & 266.236 \\
\hline 2010 & 666.541 & 301.859 \\
\hline 2011 & 968.398 & 89.252 \\
\hline 2012 & 1.057 .924 & 658.302 \\
\hline 2013 & 1.716 .226 & \\
\hline
\end{tabular}

Sumber: Laporan SHU dan Neraca KPRI Karya Bhakti, data diola

Berdasarkan tabel di atas, dapat diketahui bahwa modal pinjaman yang dikumpulkan dan dimiliki koperasi perkembangannya setiap tahun selalu mengalami kenaikan. Pada tahun 2008 ke tahun 2009 modal pinjaman mengalami kenaikan sebesar Rp. 24.402.000. Tahun 2010 modal pinjaman koperasi juga mengalami kenaikan sebesar Rp. 266.236.000 dibanding 2009. Kenaikan tersebut juga berlanjut pada tahun 2011 sebesar Rp. 301.859.000 dibanding tahun 2010. Tahun 2012 modal pinjaman juga meningkat sebesar Rp. 89.252.000. dan pada tahun 2013 modal pinjaman koperasi juga meningkat sebesar Rp. 658.302.000 dibanding tahun 2012.

Kenaikan modal pinjaman koperasi terbesar terjadi pada tahun 2013 yang dengan persentase sebesar $62,23 \%$. Meningkatnya modal pinjaman disebabkan karena koperasi saat ini sangat membutuhkan modal yang besar untuk kegiatan usahanya yang membutuhkan modal yang cukup banyak agar usahanya tetap berjalan dengan lancar.

Tabel 6 Analisis Trend Modal Pinjaman Pada KPRI Karya Bhakti

Provinsi Sulawesi Tengah Periode 2008 - 2013

\begin{tabular}{|c|c|c|c|c|}
\hline Tahun & $\begin{array}{c}\text { Modal Pinjaman (Y) } \\
\text { Dalam Rp. Ribuan }\end{array}$ & $\mathrm{X}$ & $\mathrm{XY}$ & $\mathrm{X}^{2}$ \\
\hline 2008 & 375.899 & -5 & -1.879 .495 & 25 \\
\hline 2009 & 400.301 & -3 & -1.200 .903 & 9 \\
\hline 2010 & 666.537 & -1 & -666.537 & 1 \\
\hline 2011 & 968.396 & 1 & 968.396 & 1 \\
\hline 2012 & 1.057 .921 & 3 & 3.173 .763 & 9 \\
\hline 2013 & 1.716 .223 & 5 & 8.581 .115 & 25 \\
\hline Jumlah & 5.185 .277 & 0 & 8.976 .339 & 70 \\
\hline
\end{tabular}

Sumber: Laporan Neraca KPRI Karya Bhakti, data diola 
Untuk mencari nilai a dan b sebagai berikut :

$\mathrm{a}=5.185 .277 / 6=$

$864.213 \mathrm{~b}=8.976 .339 / 70=$

128.233

Persamaan garis liniernya adalah $\mathrm{Y}=864.213+128.233 \mathrm{X}$.

1. Berdasarkan persamaan tersebut untuk meramalkan modal pinjaman tahun 2014 adalah : $\mathrm{Y}=$ $864.213+128.233$ ( untuk tahun 2014 nilai $X$ adalah 7) sehingga : $Y=864.213+897.631=$ 1.761.844 yang artinya modal pinjaman pada tahun 2015 diperkirakan sebesar 1.761 .844 atau Rp. 1.761.844.000

2. Modal pinjaman tahun 2015 adalah : $\mathrm{Y}=864.213+128.233$ ( untuk tahun 2015 nilai $\mathrm{X}$ adalah 9) sehingga : $\mathrm{Y}=864.213+1.154 .097=2.018 .310$ yang artinya modal pinjaman pada tahun 2015 diperkirakan sebesar 2.018.310 atau Rp. 2.018.310.000

3. Modal pinjaman untuk tahun 2016 adalah : $\mathrm{Y}=8864.213+128.233$ ( untuk tahun 2016 nilai $\mathrm{X}$ adalah 11) sehingga : $\mathrm{Y}=864.213+1.410 .563=2.274 .776$ yang artinya modal pinjaman pada tahun 2014 diperkirakan sebesar 2.274.776 atau Rp. 2.274.776.000

Modal pinjaman untuk tahun 2017 adalah : $\mathrm{Y}=8864.213+128.233$ ( untuk tahun 2017 adalah $: \mathrm{Y}=864.213+128.233$ ( untuk tahun 2017 nilai $\mathrm{X}$ adalah 13) sehingga $: \mathrm{Y}=864.213+1.667 .034=$ 2.531.247 yang artinya modal pinjaman pada tahun 2017 diperkirakan sebesar 2.531.247 atau Rp. 2.531.247.000.

\section{Pembahasan \\ Perkembangan modal pinjaman pada KPRI Karya Bhakti Provinsi Sulawesi Tengah}

Berdasarkan hasil penelitian pada KPRI Karya Bhakti, bahwa modal pinjaman yang dimiliki KPRI Karya Bhakti mengalami perkembangan yang baik. Hal ini dapat dilihat pada perkembangan modal pinjaman koperasi yang selalu meningkat ditiap tahunnya.

Modal pinjaman KPRI Karya Bhakti berasal dari simpanan sukarela, berasal dari bank dan lembaga keuangan lainnya, dana penyisihan sisa hasil usaha dan hutang usaha. Modal Pinjaman selalu mengalami kenaikan ditiap tahun, kenaikan ini disebabkan kesadaran anggota koperasi terhadap kebutuhan akan modal KPRI Karya Bhakti tersebut sehingga simpanan sukarela koperasi meningkat tiap tahunnya. Dan juga terjadi penungkatan modal pinjaman yang berasal dari bank dan lembaga keuangan lainnya yaitu pada tahun 2008 menerima bantuan dari luar sebesar Rp. 188.705.000 dan mengalami peningkatan sampai dengan tahun 2013 sebesar Rp. 1.319.461.000 kenyataan tersebut menunjukan bahwa semakin besar penggunaan modal pinjaman maka semakin kecil laba bersih yang dihasilkan karna adanya beban bunga sehingga nilai rentabilitas yang dihasilkan juga semakin menurun, hal ini disebabkan karna penggunaan modal pinjaman terdapat beban bunga yang akan mengurangi pendapatan, sehingga nilai rentabilitas ekonomi yang diperoleh semakin kecil.

Koperasi Pegawai Republik Indonesia (KPRI) Karya Bhakti sangat membutuhkan aliran dana dari luar untuk menunjang perkembangan usaha pada KPRI Karya Bhakti. Hal inilah yang mengakibatkan koperasi meningkatkan jumlah modalnya melalui modal pinjaman sehingga modal pinjaman juga mengalami kenaikan. Jika hanya mengandalkan modal sendiri yang terbatas, KPRI Karya Bhakti tidak dapat mencapai tujuan yang diinginkan yaitu untuk mensejahterakan anggotanya, maka dari itu koperasi harus melakukan pinjaman dari bank atau koperasi lain yaitu ke BKE untuk menambah permodalan koperasi. Dengan adanya penambahan modal yang dilakukan pihak koperasi, diharapkan hal tersebut dapat membantu untuk kelancaran usaha yang dimiliki kopeasi sehingga KPRI Karya Bhakti dapat mengembangkan usahanya untuk kesejahteraan anggota.

\section{Perkembangan Rentabilitas Ekonomi pada KPRI Karya Bhakti Provinsi Sulawesi Tengah}

Tingkat rentabilitas ekonomi sangat penting bagi Koperasi, sebab rentabilitas mencerminkan kemampuan modal suatu perusahaan untuk menghasilkan keuntungan. Semakin tinggi tingkat rentabilitas suatu perusahaan berarti semakin tinggi/naik pula tingkat efisiensi penggunaan modalnya.

Berdasarkan hasil penelitian perkembangan rentabilitas ekonomi pada KPRI Karya Bhakti pada periode 2008 - 2013 mengalami fluktuatif yaitu peningkatan terbesar pada tahun 2012 dengan nilai rasio rentabilitas ekonomi sebesar 32,24\%. Hal ini menunjukan bahwa KPRI Karya Bhakti pada tahun 2012 efektif dan efisien menggunakan modalnya, dalam ari manajemen koperasi mampu 
memenfaatkan modal yang dimiliki untuk biaya oprasional sehingga perputaran modal berjalan dengan lancar dan memberikan keuntungan bagi koperasi. Dan pada tahun 2008 KPRI Karya Bhakti memiliki nilai rasio rentabilitas ekonomi terendah yaitu sebesar $19,04 \%$, hai ini menunjukan bahwa tingkat efisiensi dan efektifitas penggunaan modal yang rendahBerarti bahwa manajemn koperasi kurang mampu memanfaatkan modal kerjanya dibanding dengan tahun-tahun berikutnya yang mana untuk membiayai atau membelanjai kegiatan operasionalisasi dari jenis-jenis usaha pada koperasi sehingga perputaran modal tidak terlalu menguntungkan untuk koperasi.

Berdasarkan analisis trend pada tahun 2014 - 217 rentabilitas ekonomi selalu mengalami peningkatan ditiap tahunnya hal ini menunjukan pada periode tahun 2014 - 2017 KPRI Karya Bhakti diramalkan mampu memanfaatkan modal yang dimiliki untuk kopersi tersebut sehingga perputaran modal berjalan dengan lancar dan memberikan keuntungan pada koperasi.

Sesuai dengan teori oleh Munawir (2012) yang menyatakan jika biaya operasional yang dikeluarkan rendah maka laba yang diperoleh lebih kecil sehingga menyebabkan menurunnya rentabilitas ekonomi perusahaan. Sebaliknya, jika biaya operasional yang dikeluarkan tinggi maka laba yang diperoleh lebih besar sehingga meningkatnya rentabilitas ekonomi. Dan didukung oleh penelitian yang dilakukan Sukardi Ikhsan (2011) dengan judul "Analisis Rentabilitas pada KPRI di Jawa Tengah" dimana pengandalian biaya operasional berpengaruh terhadap rentabilitas ekonomi.

\section{Perkembangan Modal Pinjaman dan Rentabilitas Ekonomi pada KPRI Karya Bhakti Provinsi Sulawesi Tengah}

Berdasarkan hasil penelitian perkembangan modal pinjaman dan rentabilitas ekonomi pada KPRI Karya Bhakti menunjukan bahwa modal pinjaman yang dimiliki oleh KPRI Karya Bhakti tiap tahunnya mengalami peningkatan yang berarti bahwa semakin besar penggunaan modal pinjaman maka semakin kecil laba bersih yang dihasilkan karna adanya beban bunga sehingga nilai rentabilitas yang dihasilkan juga semakin menurun, hal ini disebabkan karna penggunaan modal pinjaman terdapat beban bunga yang akan mengurangi pendapatan, sehingga nilai rentabilitas ekonomi yang diperoleh semakin kecil. Bertambahnya modal pinjaman berarti akan memberi peluang pada koperasi untuk mengembangkan usahanya, berarti pula akan memberikan peluang bagi koperasi untuk mendapatkan laba yang sudah pasti memberbesar rasio rentabilitas ekonomi. Namun sebaliknya pada KPRI Karya Bhakti bertambahnya modal pinjaman dan bertambahnya laba tetapi tidak dibarengi dengan bertambahnya rasio rentabilitas ekonomi dalam penelitian ini juga ditemukan bahwa modal pinjaman selalu naik ditiap tahunnya tetapi nilai rentabilitas ekonomi yang dihasilkan naik turun atau berfluktuasi, dalam hal ini pihak koperasi perlu mempertimbangkan dalam manajemen penggunaan modal pinjaman tersebut yaitu kebijakan dalam menentukan dan mengoptimalkan sumber dana sesuai dengan kebutuhan usaha pada koperasi.

Modal pinjaman yang meningkat tiap tahunnya menunjukan indikator bahwa modal koperasi sendiri belum cukup untuk membiayai oprasional usahanya dan usaha yang dijalankan membutuhkan modal yang beasar dan juga Rendahnya tingkat perputaran modal pinjaman sehingga menunjukan adanya kelebihan modal pinjaman disebabkan karena adanya kelebihan dana yang diinvestasikan pada piutang dan rendahnya pendapatan dan penjualan. Hal ini juga dapat disebabkan karena pengurus koperasi kurang memperhatikan dan memanfaatkan modal pinjamannya dengan baik dimana koperasi hanya berusaha mengembangkan modal pinjaman tetapi tidak dibarengi dengan langkah-langkah mengembangkan usaha sehingga pada KPRI Karya Bhakti Provinsi Sulawesi Tengah mempunyai modal pinjaman yang besar tiap tahunnya namun modalnya kurang dikembangkan sehingga kurang mendapatkan SHU yang maksimal. Dengan adanya modal pinjaman yang cukup akan memungkinkan suatu koperasi untuk dapat beroperasi dengan seekonomis mungkin, akan tetapi modal pinjaman yang berlebihan menunjukan adanya dana yang tidak produktif dan hal ini akan menimbulkan kerugian bagi perusahaan. Untuk itu hendaknya seluruh pengurus koperasi atau para anggota koperasi dan yang bersangkutan harus benar-benar mengoptimalkan penggunaan modal pinjaman dalam mengoperasikan usaha koperasi dengan melakukan perputaran modal pinjaman yang tinggi sehingga pencapaian laba akan optimal dan mempertimbangkan jenis usaha koperasi tersebut serta dilihat dari tingkat penjualannya, efisiensi biaya operasional, profit margin, dan struktur modal pada koperasi. Hal ini didukung oleh teori dari Riyanto (2010) yang mengungkapkan tingkat suku bunga mempengaruhi rentabilitas ekonomi. Dan teori oleh Munawir (2012) yang memgungkapkan perputaran piutang mempengaruhi rentabilitas ekonomi karena semakin tinggi perputaran piutang maka semakin rendah 
rentabilitas. Serta didukung hasil penelitian oleh Apriyanti,dkk (2013) dimana menunjukan bahwa perkembangan modal mengalami kenaikan ditiap tahunnya sedangkan perkembangan pendapatan usaha mengalami kenaikan dan penurunan.

\section{KESIMPULAN DAN SARAN \\ Kesimpulan}

Berdasarkan hasil analisis data dan pembahasan penelitian mengenai Analisis modal pinjaman dan rentabilitas ekonomi pada KPRI Karya Bhakti Provinsi Sulawesi Tengah, dapat disimpulkan sebagai berikut:

1. Besarnya modal pinjaman pada KPRI Karya Bhakti selama periode 2008 -2013 terlihat mengalami peningkatan ditiap tahunnya, hal ini disebabkan karna adanya perkembangan usaha yang dikelola koperasi dimana modal pinjaman dibutuhkan untuk mendukung atau membiayayi kegiatan oprasional usaha koperasi.

2. Rentabilitas ekonomi pada KPRI Karya Bhakti selama periode 2008 -2013 terlihat mengalami naik turun atau berfluktuatif, rentabilitas ekonomi tertinggi terjadi pada tahun 2012 dengan nilai sebesar 32,24\%, Hal ini memberikan arti bahwa setiap penambahan modal sebesar Rp. 1 maka KPRI Karya Bhakti mampu mendapatkan keuntungan sebesar Rp. 0,3224. Hal ini menunjukan KPRI Karya Bhakti pada tahun 2012 efektif dan efisien menggunakan modalnya. Dan rentabilitas ekonomi terendah terjadi pada tahun 2008 yaitu sebesar 19,04\%, hai ini menunjukan bahwa tingkat efisiensi dan efektifitas penggunaan modal yang rendah, dimana modal sebesar Rp. 1 hanya dapat menghasilkan Rp. 0,1904. Berarti bahwa manajemn koperasi kurang mampu memanfaatkan modal kerjanya dibanding dengan tahun-tahun berikutnya.

3. Berdasarkan hasil analisis trend dan pembahasan dapat disimpulkan bahwa modal pinjaman dan Rentabilitas ekonomi pada tahun 2014 - 2017 cenderung mengalami peningkatan ditiap tahunnya.

\section{Saran}

Berdasarkan pada analisis dan kesimpulan yang berkaitan dengan penelitian ini, maka saransaran yang dapat diajukan dalam penelitian ini adalah:

1. Dalam menjalankan kegiatan operasional koperasi perlu adanya perencanaan atau pertimbangan yang matang untuk menentukan seberapa besar penggunaan modal pinjaman, khususnya hutang jangka panjang hal ini untuk mencegah koperasi kesulitan untuk membayar hutang-hutang yang dapat berdampak mengurangi kepercayaan kreditur, yang kemudian dapat berakibat turunnya nilai perusahaan. Dan untuk menambah modal pinjaman koperasi khususnya modal pinjaman yang berasal dari pihak luar seperti bank, koperasi hendaknya memperhatikan kelayakan usaha atau tingkat likuditas koperasi.

2. Agar pendapatan koperasi selalu mengalami peningkatan seperti permodalan koperasi, maka anggota harus lebih aktif untuk melakukan simpan pinjam di USP, selalu berbelanja di toko KPRI Karya Bhakti, karena dengan begitu pendapatan yang diperoleh koperasi semakin banyak.

3. Koperasi hendaknya mengusahakan modal pinjaman dari dalam koperasi itu sendiri yaitu modal pinjaman yang berasal dari anggota koperasi yaitu simpanan sukarela anggota, hal tersebut lebih baik dibandingkan dengan pemanfaatan modal pinjaman yang berasal dari luar koperasi seperti bank dikarenakan memiliki beban finansial berupa bunga.

4. Untuk penelitia yang akan datang yang ingin melakukan penelitian terhadap rentabilitas ekonomi pada KPRI disarankan untuk menambahkan variabel independen lain selain modal pinjaman, karna pada penelitian ini pengaruh variabel lain selain modal pinjaman juga memiliki pengaruh yang besar rentabilitas ekonomi pada KPRI Karya Bhakti.

\section{REFERENSI}

Andriani, Eka Novi. (2009) "Pengaruh Modal Sendiri dan Modal Pinjaman Terhadap Tingkat

Rentabilitas Pada Koperasi Serba Usaha (KSU) di Kabupaten Blora”. E-Journal UNNES Uneversitas Negeri Semarang, vol 1. 
Apriyanti, Alit Nur, dan Kirwani. (2013). Analisis Perkembangan Modal dan Pendapatan Usaha Koperasi Dalam Rangka Meningkatkan Sisa Hasil Usaha di KPRI Harapan Mojokerto.

Buku Laporan Koperasi Pegawai Republik Indonesia Karya Bhakti, 2013. Provinsi Sulawesi Tengah. Hasibuan, Malayu S.P. 2011. Dasar-Dasar Perbankan, PT Bumi Aksara, Jakarta. Ikhsan, Sukardi. (2011). "Analisis Rentabilitas pada Koperasi Pegawai Republik Indonesia (KPRI) di Jawa Tengah". EJournal UNNES Universitas Negeri Semarang, vol 3.

Karjono, Albertus dan Amelia Falah Fakrina. (2012). "Pengaruh Perputaran Kas dan Perputaran Piutang Terhadap Rentabilitas Ekonomi Pada KPRI di Lingkungan BKN”. ESENSI, Vol 15 (2), 28-45.

Kasmir, 2014. Analisis Laporan Keuangan Ed. 1-7 Jakarta: Rajawali Pers.

Miranty, Diah. (2013). Pengaruh Perputaran Piutang dan Efisiensi Modal Kerja Terhadap Rentabilitas Ekonomi pada KPRI Gotong Royong Kedungprig Lamongan.

Mukhlis. (2006). Pengaruh Modal Pinjaman Terhadap Rentabilitas Ekonomi pada Koperasi Pegawai Negeri (KPN) di Kota Palu.

Munawir, S. (2012). Analisa Laporan Keuangan (Edisi 4) Liberty Yogyakarta.

Riyanto, Bambang. (2010). Dasar-Dasar Pembelajaran Perusahaan (Edisi 4) BPFE Yogyakarta.

Sugiono, 2013.Metode Penelitian Bisnis, Bandung: Alfabeta

Umar, Husein. (2013). Metode Penelitian untuk Skripsi dan Tesis BisnisEd2.-12,Rajawali Pers,Jakarta.

Widiantari, Made Ita, I Ketut Suwarna dan I Wayan Suwendra. (2014). "Pengaruh Tingkat Suku

Bunga Dan Perputaran Piutang Terhadap Rentabilitas Ekonomi Pada Koperasi".E-Journal Bisma Universitas Pendidikan Ganesha, Vol 2. 